Asian J Agric \& Biol. 2021(2).

\title{
Application of plant growth promoters on sugarcane (Saccharum officinarum L.) budchip under subtropical conditions
}

\author{
Abdul Rehman1, Farwa Hassan1, Rafi Qamar1*, Atique-ur-Rehman² \\ ${ }^{1}$ Department of Agronomy, College of Agriculture, University of Sargodha, Pakistan \\ ${ }^{2}$ Department of Agronomy, Bahauddin Zakariya University, Multan, Pakistan
}

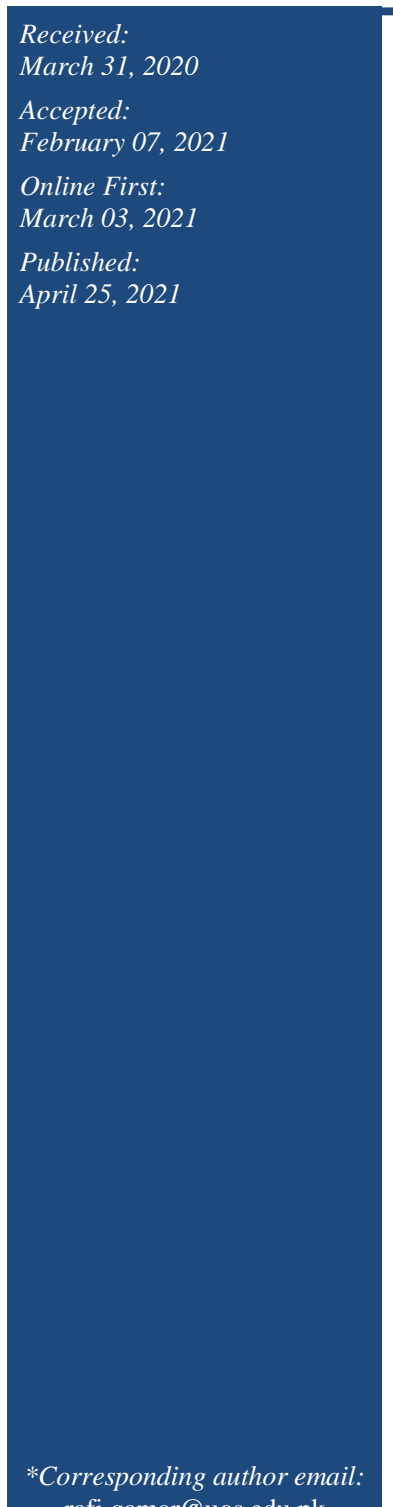

\begin{abstract}
Sugarcane (Saccharum officinarum L.) budchip technology is a viable alternative of conventional sett planting, where excised auxiliary buds are used as planting material. Plant growth promoters (PGPs) have ability to enhance growth of plants and thus applied to improve production. The objective of this study was to enhance the sprouting and early growth of sugarcane budchips through exogenous application of plant growth promoters and $\mathrm{CaCl}_{2}$. It was hypothesized that application of growth regulators on budchips will improve the growth and yield of sugarcane. Keeping in view, a pot study was planned to elaborate priming effects of PGPs on sprouting and growth of sugarcane budchips, prepared by budchip scooping machine. The study was executed at Agronomic Research Area, College of Agriculture, University of Sargodha, Sargodha for two consecutive years during spring 2015 and 2016. Experiment was arranged under completely randomized design (CRD) having four treatments i.e. Control, NAA $1 \mathrm{mM}, \mathrm{CaCl}_{2} 1 \mathrm{mM}$, NAA $1 \mathrm{mM}+\mathrm{CaCl}_{2} 1 \mathrm{mM}$. It was observed that sugarcane budchips treated with NAA $1 \mathrm{mM}+\mathrm{CaCl}_{2} 1 \mathrm{mM}$ gave higher sprouting establishment percentage, produced taller and thicker plants, exhibited higher leaf area index and chlorophyll contents as compared to all other treatments during each year of study. Similarly, more root length, root fresh weight, root dry weight, shoot length, shoot fresh weight and shoot dry weight was achieved with application of treatment combination; NAA $1 \mathrm{mM}+\mathrm{CaCl}_{2} 1 \mathrm{mM}$ over all others including control during both years. Among all PGPs treatments, $\mathrm{CaCl}_{2} 1 \mathrm{mM}$ had minimum effect on all studied parameters of sugarcane but it was statistically at par with NAA $1 \mathrm{mM}$. The results of this study led to the conclusion that soaking of sugarcane budchips in NAA $1 \mathrm{mM}+\mathrm{CaCl}_{2} 1 \mathrm{mM}$ solution proved to be superior than all other PGPs treatments and control as it promotes early growth, better establishment of seedlings and improve its other characteristics.
\end{abstract}

Keywords: Sugarcane, Budchip scooping machine, Budchips, Plant growth promoters, Soaking

\section{How to cite this:}

Rehman A, Hassan F, Qamar R and Rehman AU, 2021. Application of plant growth promoters on sugarcane (Saccharum officinarum L.) budchip under subtropical conditions. Asian J. Agric. Biol. 2021(2): 202003202. DOI: https://doi.org/10.35495/ajab.2020.03.202

This is an Open Access article distributed under the terms of the Creative Commons Attribution 3.0 License. (https://creativecommons.org/licenses/by/3.0), which permits unrestricted use, distribution, and reproduction in any medium, provided the original work is properly cited. 


\section{Introduction}

Sugarcane (Saccharum officinarum L.) has second position in the list of cash crop and significant contribution in the agro-based and other allied industries of Pakistan (Naqvi, 2005). Moreover, Pakistan ranks $4^{\text {th }}$ in respect of acreage and production, however, its level of yield is ranked $53^{\text {rd }}$ in the world (FAO, 2019). The production of sugarcane accounts $2.9 \%$ and $0.5 \%$ in value addition and overall gross domestic product of Pakistani agriculture respectively. Sugarcane was cultivated on an area of 1.10 million ha with annual stripped cane yield of 67.17 million tons and having $60956 \mathrm{~kg} \mathrm{ha}^{-1}$ average yield (Govt. of Pakistan, 2018-2019). In Pakistan, it is significant source of providing employment opportunities directly or indirectly to over four million peoples (Naqvi, 2005). Moreover, it is a perennial crop and conventionally propagated through stem cuttings called setts that having 2-3 buds with length of 25-30 $\mathrm{cm}$ (Patnaik et al., 2016). In various operations of sugarcane production, considerable number of human drudgery required due to labor intensive crop. Thus, its production can adversely affect due to labour shortage. For conventional planting, 6-8 ton stalk pieces or 30,000 setts per hectare are required, which is the $10 \%$ of total crop production (Jain et al., 2010). However, analysis of the cost components shows that this conventional planting method and seed cost largely affect the economics of sugarcane production estimating $16 \%$ of the total cost of production (Dharmawardene, 2006). Hence, there are a lot of problems associated with this mass of planting material i.e. transport, setts treatment, handling and storage. It was seen that this bulk undergoes quick deterioration and decreasing the feasibility of cane buds leading to poor sprouting (Loganandhan et al., 2013).

Focusing on budchip technology in future would be the best alternative way for reducing the seed cane quantity and the cost that accordingly leads to enhance the net returns to sustain sugarcane production (Mohanty and Nayak, 2011). Budchip consists of small portion of tissue with root primordium, which has the ability to sprout into a sugarcane plant. These budchips can be used for commercial planting (Iqbal et al., 2002) and perform well under suitable growing conditions. Budchip planting method is economical, possess less bulky seed and can be easily transported as compared to conventional planting (Patil et al., 2018). Moreover, only 2 to 3 quintals of budchips are enough for planting of one hectare, and subsequently saves about $80 \%$ of the sugarcane in term of weight (Iqbal et al., 2002). However, there are some limitation which may be faced by adopting this technology i.e. poor shelf life under field conditions, rapid depletion of moisture and food reserves that all leads to poor sprouting establishment and growth of budchips (Jain et al., 2010). Many agricultural techniques have been spring up and implemented to enhance the shelf life, sprouting percentage and quality of budchips, whereas application of growth regulators is one of them (Leite et al., 2011).

Basically, plant growth promoters (PGPs) bring a modification in the plant metabolic and physiological responses that favored the seedling establishment and sprouting percentage (Hayat et al., 2010). The primary purpose for application of PGPs are to enhance the germination, rooting volume, vegetative growth and yield attributes of plants. Pre-sowing seed treatment of bud chip with growth regulators significantly improved seedling germination and vigor (Paul and Savithri, 2003). Moreover, budchip treated with PGPs are having enhanced concentration of reducing sugar, water and nutrient use efficiency and resistance against pests (Wu and Birch, 2007). Solomon et al. (2001) stated that PGPs improved 30-35 \% higher sprouting percentage and root shoot ratio of budchip than the untreated budchip. Budchip treated with PGPs when planted have also been testified to increase tillering and sucrose buildup in cane (Zhang et al., 2001).

Calcium is an alimentary plant nutrient in plant food, which is used as PGPs due to its dominant duty in cell membrane and wall stability by acting as cation in plant vacuole and having role as secondary messenger in transferring exogenous and endogenous signals in cytoplasm (White and Broadley, 2003). Moreover, it involves in the stimulation of enzymes e.g. phospholipase, amylase, lecithinase and ATPase (Hepler, 2005). Calcium chloride and ethephon are used as a growth-stimulating agent and showed marvelous effects on aerial and underground parts development of sugarcane buds (Jain et al., 2009). Indole acetic acid (IAA) has dominant role in different developmental processes for example rooting volume, cell elongation, apical dominance, flower formation and vascular tissues growth and differentiation (Zhao, 2010). Optimum concentrations of PGPs in sugarcane are helpful for shoot regeneration (Chengalrayan et al., 2005). Moreover, pre-seed treatment of PGPs remarkably increased internodal length in sugarcane (Iqbal et al., 2011). Plant growth promoters have 
prominent role for upgrading the sugarcane growth and development that has been found effective in improving its productivity (Li and Solomon, 2003). Advanced as well as earlier sprouting along with maximum tiller production was found due to adequate application of ethephon ( $\mathrm{Li}$ and Solomon, 2003). Reddy et al. (2009) said that yield attributes of crop were increased by the application of naphthalene acetic acid (NAA). Significant multiplication of sugarcane by callus, axillary bud, shoot tip and sucrose concentrations was recorded when optimum dose of NAA applied on sugarcane budchip (Khan et al., 2009). However, no information is available on the collective application of $\mathrm{Ca}$ and NAA and its effect on different cane growth and developmental characters. Hence, a pot experiment was aimed to improve sprouting establishment, tillering, height, fresh and dry weight of root and shoot and leaf area index of budchip by the pre-seeded application of $\mathrm{Ca}$ and NAA on sugarcane budchip under the semi-arid environment of Sargodha. It is our hypothesis that application of growth regulators will improve the growth of buds obtained from budchip machine and hence improve the efficiency of this system.

\section{Material and Methods}

\section{Experimental site and soil}

A wire-house experiment was conducted for the two consecutives sugarcane growing seasons of 2015 and 2016 at College of Agriculture, University of Sargodha, in district Sargodha located at $32.08{ }^{\circ} \mathrm{N}$, $72.67^{\circ} \mathrm{E}$ and $193 \mathrm{~m}$ altitude. Climatic feature of district Sargodha is subtropical to semiarid having $400 \pm 5 \mathrm{~mm}$ annual rainfall. Monsoon seasons started in July and ended in September which received $70 \%$ of the total rainfall (Agro-Metrological Lab, University of Sargodha). Mean minimum temperature were about 10 ${ }^{\circ} \mathrm{C}$ in winter season.

Earthen pots $\left(25 \times 40 \mathrm{~cm}^{-2}\right)$ filled with $20 \mathrm{~kg}$ sandy clay loam soil and covered with polyethylene sheet having bulk density $\approx 1.04 \mathrm{mg} \mathrm{m}^{-3}$ (Paull et al., 1998). The water holding capacity and field moisture capacity were maintained with $33 \%$ and $70 \%$ with ionize free water, respectively. Before conducting experiment, soil was air-dried, crushed and pass through $2 \mathrm{~mm}$ sieve for analyzed different physico-chemical properties. Soil was weighted and filled the experimental pots 7 days before planting (Aitken and McCallum, 1988). Before conducting experiment, air- dried soil was crushed and sieved out from sieve having size of $2 \mathrm{~mm}$ for performing different physicochemical properties by the methods of Ryan et al. (2001). Hydrometer techniques was applied for finding of soil textural class and it was sandy clay loam that appropriate to Hafizabad soil series (fine-loamy, mixed, hyperthermic, Typic Calciargids) (Khan, 1986). Soil pH and EC were $7.8 \pm 0.1$ and $2.19 \pm 0.3 \mathrm{dS} \mathrm{m}^{-1}$ that were measured by utilizing a pH meter (Beckman 45 Modal, US) and EC meter (VWR Conductivity Meter DIG2052), respectively. Soil organic matter content was $0.72 \%$ measured through Walkely-Block strategy, $\mathrm{N}$ was $600 \mathrm{mg} \mathrm{kg}^{-1}$ through Modified Kjeldahl Method, extractable-P was $60 \mathrm{mg} \mathrm{kg}^{-1}$ through Olsen's Method and available potassium was $80 \mathrm{mg} \mathrm{kg}^{-1}$ through Flame photometric. Wire-house temperature and humidity was maintained in the range between 26 ${ }^{\circ} \mathrm{C}$ to $30{ }^{\circ} \mathrm{C}$ and $60 \%$ to $65 \%$ at noontime, respectively

\section{Experimental design and treatments}

A pot experiment was performed in a completely randomized design having four replications to evaluate the role of plant growth promoters viz., control (water soaked), $\mathrm{CaCl}_{2}$ (calcium chloride) $1 \mathrm{mM}$, NAA (naphthaleneacetic acid) $1 \mathrm{mM}$ and $\mathrm{CaCl}_{2} 1 \mathrm{mM}+$ NAA $1 \mathrm{mM}$ on germination and early establishment of budchip at College of Agriculture, University of Sargodha. The budchips were scooped from a freshly harvested cultivar ( $c v . N S G 59$ ) with a petrol engineoperated budchip scooping machine (Figure 1 Patent Number 143641); Machine designed and fabricated by Dr. Abdul Rehman (Department of Agronomy, College of Agriculture, University of Sargodha, Sargodha, Pakistan); Dr. Muhammad Rafi Qamar (Department of Agronomy, College of Agriculture, University of Sargodha, Sargodha, Pakistan) and Dr. Atique-urRehman (Department of Agronomy, Bahauddin Zakariya University, Multan, Pakistan). For the preparation of $1 \mathrm{mM} \mathrm{CaCl}_{2}$ and NAA solution $1 \mathrm{~mL}$ of their $1 \mathrm{M}$ stock standard solution was added per liter of distilled water at room temperature $\left(25 \pm 1{ }^{\circ} \mathrm{C}\right)$. Fungicide (Thiophenate methyle) @ $1.5 \mathrm{~g} /$ lit. of water. Sugarcane budchips were dipped into the solution for 3 to 5 mint. and then shade dried. Budchips were soaked in respective solution for $2 \mathrm{~h}$. Afterwards, these budchips were sacked, and dumped in, for $6 \mathrm{~d}$. Sprouted budchips were taken out from soil. 


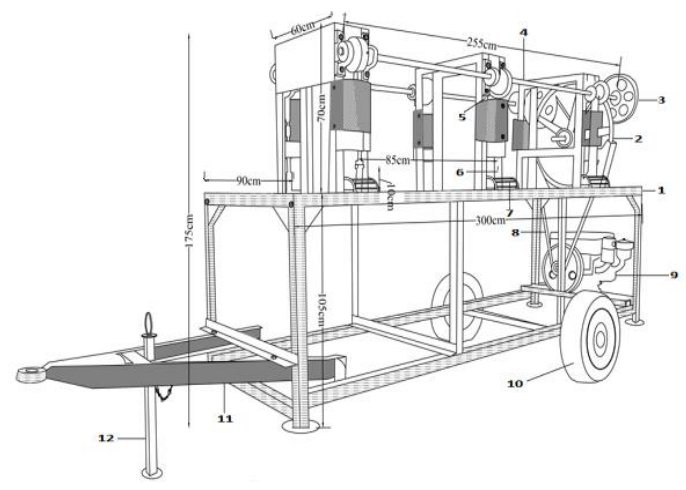

Figure-1. Budchip scooping machine (Basic parts; 1- Main frame; 2- Large pulley; 3-Small pulley; 4Shaft/beam; 5- Cam; 6- Cutter; 7- Protecting cover; 8- Belt; 9- Peter engine; 10- Wheel; 11- Vshaped hook; 12- Stand)

[Intellectual Property Organization Karachi Pakistan; Electronic Publication of Patents Journal under The Patents (Amendments) Act, 2016; (Patent Number 143641)]

\section{Crop husbandry}

A total of 06 sprouted budchips were sown in each pot at the depth of $3.8 \mathrm{~cm}$ on $15^{\text {th }}$ February, 2015 and 2016 and plants were thinned to two at 20 days after sowing (DAS). Soil in the pots were examined and retained at soil water up to $70 \%$ by weight on daily basis. Recommended fertilizer doses of N, P and K @ 120, 70 and $50 \mathrm{~kg} \mathrm{ha}^{-1}$ were uniformly applied and mixed thoroughly into the soil on soil weight basis. Budchips were grown till 90 days and uprooted on $30^{\text {th }}$ May, 2015 and 2016. During study period, standard production practices were adopted and plants were kept free of insect-pests through using pesticide sprays. After 3 months' experiment was discontinued and sugarcane plants were immersed in water for 2 hours and then removed carefully.

\section{Data collection}

Sprouting establishment percentage, growth parameters viz., plant height, productive tillers, stem diameter, leaf area index, length, fresh and dry weight of roots and shoots and chlorophyll contents were noted after the harvesting of plants. For sprouting establishment percentage, plants were selected in each experimental pots and monitored regularly and sprouting percentage was calculated by the formula:

$$
S P=\frac{\text { Sprouted or germinated buds }}{\text { Total buds planted }} \times 100
$$

Meter rod was used for the measurement of plant height (cm) at maturity. Number of tillers was noted from assigned plants in each experimental pot after 90 days after sowing. Stem diameter $(\mathrm{cm})$ was recorded with the help of Vernier caliper (Truper, CALDI-6MP) from plants bottom, middle and top then averaged. Leaf area index of selected plants were measured with a leaf area meter (LI-3100, LI-COR, Lincoln, NE). Root length was determined by randomly selecting one plant was dug-out with a sampling tool having 7 $\mathrm{cm}$ sharp cutting tip. Then, soil and other residues were carefully separated from the roots through gentle washing. Root length was noted in centimeters from ground level to the root tips. For measurement of shoot length, one seedlings from each experimental pot was randomly selected and their shoot length was recorded in centimeter $(\mathrm{cm})$ from top to joining point of root and shoot. For calculation of root and shoot fresh weight, one seedling from each experimental pot was taken and their roots and shoots were separated from the junction with the help of scissor. The root and shoot fresh weight of all the samples were calculated by an analytical balance (Model Number: HC2204). Then, this weight was used to compute average root and shoot fresh weight in grams. The weighed samples of fresh roots and shoot were placed in oven at $70{ }^{\circ} \mathrm{C}$ for $72 \mathrm{~h}$ until a constant weight was obtained for calculation of root and shoot dry. This weight was used to compute average root and shoot dry weight per plant in grams. Leaf chlorophyll was determined with chlorophyll meter, model no. (SPAD-502 Plus) between 10:00 AM and 02:00 PM. Each measurement was continued three times and the means were included for analysis.

\section{Statistical analysis}

Data were statistically analyzed using Fisher's ANOVA technique, and variation among the treatment means was compared using LSD at a 5\% probability level (Steel et al., 1997). The MSTAT-C statistical package (Freed et al., 1991) was used to analyze the two year's data (2015 and 2016) in CRD combined over years. As the effects in different years were found to be significant, as shown by year, the data are presented for individual years. Graphs were created using SigmaPlot software (Systat Software, 2008).

\section{Results and Discussion}

The inducing effect of plant growth promoters (PGPs) 
i.e. calcium chloride $\left(\mathrm{CaCl}_{2}\right) 1 \mathrm{mM}$, naphthaleneacetic acid (NAA; $\mathrm{C}_{10} \mathrm{H}_{7} \mathrm{CH}_{2} \mathrm{CO}_{2} \mathrm{H}$ ) $1 \mathrm{mM}$ and combination of calcium chloride $\left(\mathrm{CaCl}_{2}\right) 1 \mathrm{mM}+$ naphthaleneacetic acid (NAA; $\mathrm{C}_{10} \mathrm{H}_{7} \mathrm{CH}_{2} \mathrm{CO}_{2} \mathrm{H}$ ) $1 \mathrm{mM}$ after soaking of sugarcane budchips on sprouting and growth parameters were studied as shown in Figure 2 and 3. Treatment of PGPs (NAA $1 \mathrm{mM}+\mathrm{CaCl}_{2} 1 \mathrm{mM}$ ) on sugarcane bud chip improved the sprouting establishment percentage over control which ranged from $96 \%$ and $98 \%$ during 2015 and 2016, respectively (Figure 2). Whereas, NAA $1 \mathrm{mM}$ alone improved $83 \%$ and $85 \%$ sprouting during 2015 and 2016, respectively, however, it was statistically at par with $\mathrm{CaCl}_{2} \quad 1 \mathrm{mM}$ during 2015. Higher sprouting percentage in all PGPs treatments over control might be due to increase in concentration of glucose, fructose and acid invertase enzymes in sprouting sugarcane buds. Our results corroborate the results of Jain et al. (2009), who described that PGPs had positive effects on the germination of underground sugarcane buds because these chemicals were linked with a consistent rise in glucose, fructose and acid invertase enzymes in developing buds. PGPs alone or in combined form significantly improve the sprouting establishment might be to enhance the activity of ATPase (Jain et al., 2009). Moreover, PGPs enhanced the potential of cytokinin that leads to stimulate cotyledon growth (White and Broadley, 2003). Mohanty and Sahoo (2000) also found that germination and sprouting of different crop plants was enhanced by application of natural and synthetic growth promoters.

Bud chip treated with combination of growth promotors (NAA $1 \mathrm{mM}+\mathrm{CaCl}_{2} 1 \mathrm{mM}$ ) showed $42 \%$ and $40 \%$ significantly taller plant height as compared to control during 2015 and 2016 respectively (Figure 2). Among growth regulator treatments, $\mathrm{CaCl}_{2} 1 \mathrm{mM}$ showed $29 \%$ and $27 \%$ shorter plant height as compared to combined (NAA $1 \mathrm{mM}+\mathrm{CaCl}_{2} 1 \mathrm{mM}$ ) application of PGPs during both years. Plant growth promoters might enhance the activity of acid invertase and ATPase, which convert the sugar into reducing form, which is direct source of food that leaded to taller plants than control (Figure 2). In similar lines, PGPs enhanced the activity of acid invertase and ATPase which increases the availability of reducing sugar. Moreover, reducing sugar serves as direct food materials to sprouting buds whereas inorganic phosphorus unrestricted due to the activity of ATPase which provides carbon and energy to the cell for producing chemicals essential for plant height (Jain et al., 2009). In our experiment, budchips soaking in PGPs improved sprouting establishment (Figure 2) and root length (Figure 3 ) of cane plants, which might increase reducing sugars as a results of acid invertase enzymes in sprouted buds that leads to promote cell division, growth, differentiation and production of sucrose in budding meristem of sugarcane (El-Lattief and Bekheet, 2012). Treated budchip with NAA $1 \mathrm{mM}$ $+\mathrm{CaCl}_{2} 1 \mathrm{mM}$ showed $43 \%$ and $44 \%$ significantly higher stem diameter over control during 2015 and 2016, respectively (Figure 2). Moreover, NAA $1 \mathrm{mM}$ alone produced $27 \%$ and $28 \%$ higher stem diameter during both years of study but it was statistically at par with $\mathrm{CaCl}_{2} 1 \mathrm{mM}$ during 2015. The number of tillers from budchip was higher due to PGPs treatment as it was significantly $31 \%$ and $32 \%$ better with application of NAA $1 \mathrm{mM}+\mathrm{CaCl}_{2} 1 \mathrm{mM}$ over control during 2015 and 2016, respectively (Figure 2). Whereas, NAA $1 \mathrm{mM}$ showed intermediate effect that was in between $\mathrm{CaCl}_{2} 1 \mathrm{mM}$ and NAA $1 \mathrm{mM}+\mathrm{CaCl}_{2}$ $1 \mathrm{mM}$ during both years. The result reveals that soaking of budchip with PGPs can be useful in improving sprouting establishment that resulted in more stem diameter and tillers (Figure 2). The significant improvement in stem diameter and number of tillers due to PGPs treatment might be due to increase in ATPase and acid invertase activity. Acid invertase is used in conversion of sucrose into reducing sugar while ATPase used in production of inorganic phosphorus, which provide energy for cell growth and development (Jain et al., 2009). PGPs exhibited significant expansion in leaf area index as it was significantly $34 \%$ higher over control treatment during study period (Figure 2). Leaf area index of NAA $1 \mathrm{mM}$ and $\mathrm{CaCl}_{2} 1 \mathrm{mM}$ were statistically at par during both years. Significant improvement in leaf area index (Figure 2) might be due to high moisture content that leads to conversion of carbohydrates into reducing sugar which favored plant growth. 
Abdul Rehman et al.
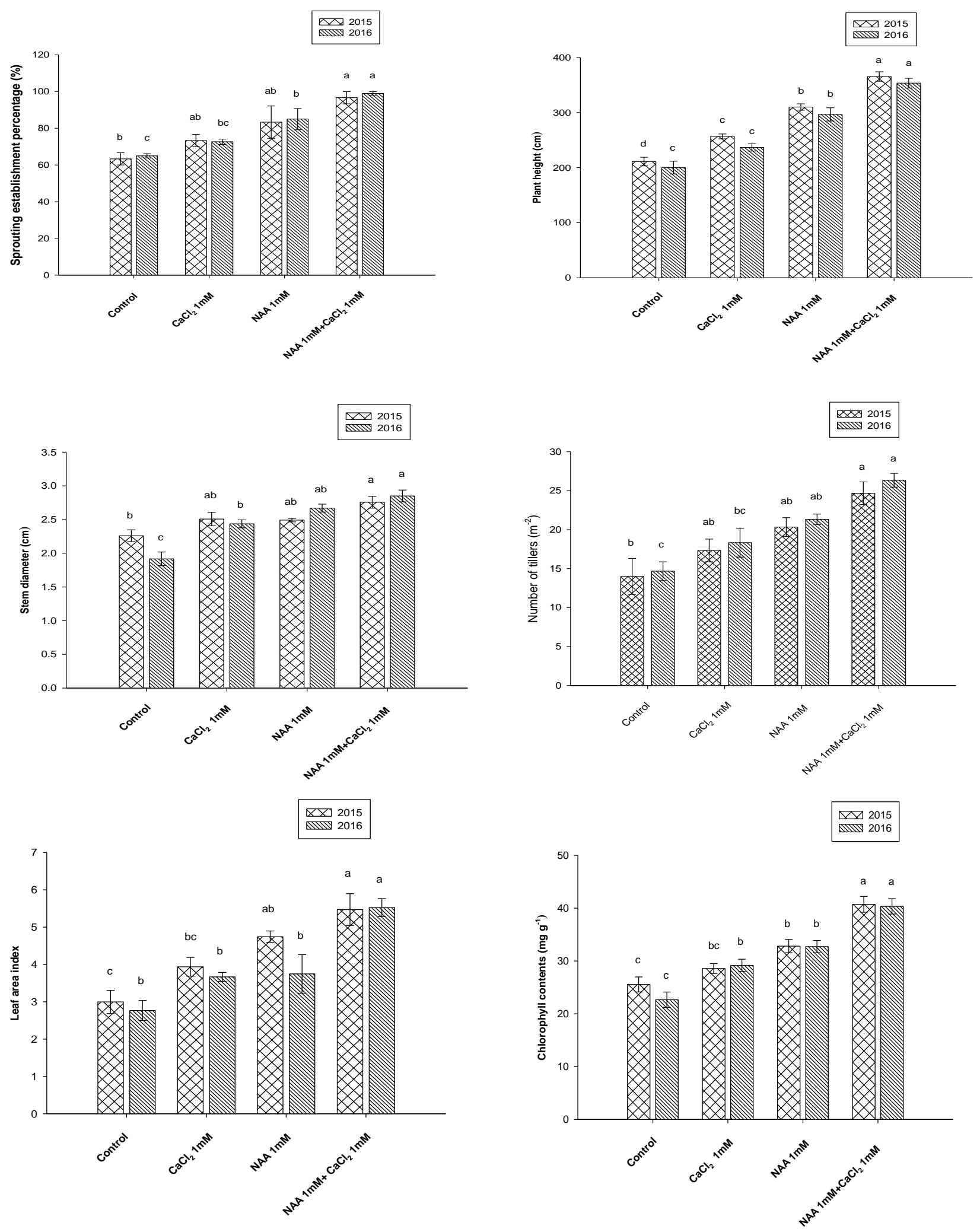

Figure-2. Growth parameters of sugarcane as affected by soaking in growth promoters. 

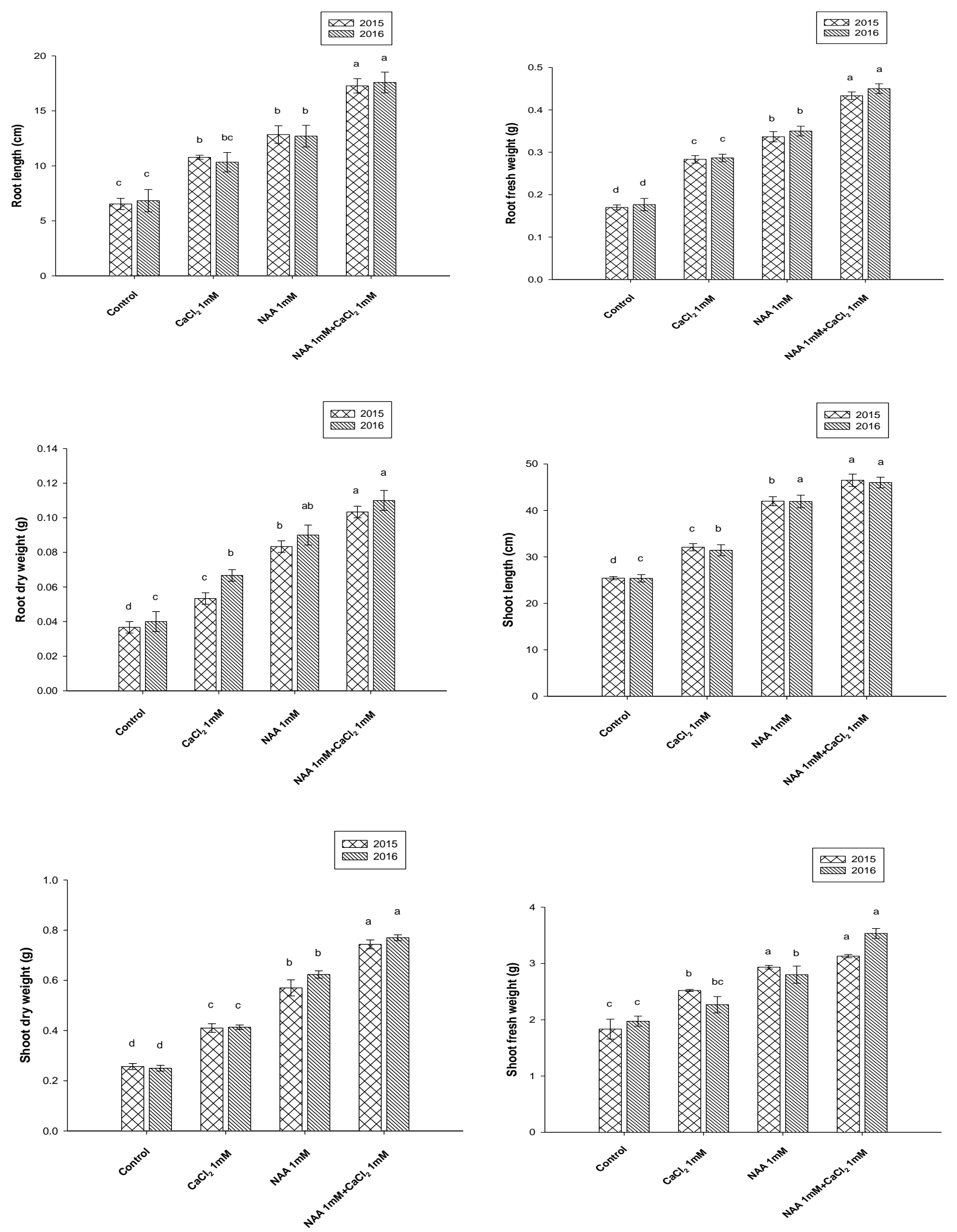

Figure-3. Root and shoot characteristics of sugarcane as affected by soaking in growth promoters. 
Our study sustained the results of Jain et al. (2007) who noted that in water soaking budchip the sucrose is converted into glucose which is rapidly mobilized and utilized by the growing point of the sugarcane bud. Chemical treatment with NAA $1 \mathrm{mM}+\mathrm{CaCl}_{2} 1 \mathrm{mM}$ produced $48 \%$ and $47 \%$ significantly higher chlorophyll contents over water soaked treatment during 2015 and 2016 respectively (Figure 2).

All PGPs treatments exhibited in better chlorophyll contents over control (Figure 2) and among chemical treatments, lower chlorophyll contents were recorded with $\mathrm{CaCl}_{2} 1 \mathrm{mM}$ during both years of study. Our findings supported the results of Iqbal et al. (2011) who reported that plant growth promoters improved the chlorophyll contents due to ATPase and acid invertase activity. Treated budchip revealed significant growth in root length, fresh and dry weight; increase was $62 \%$ and $63 \%$ in root length, $60 \%$ and $61 \%$ in root fresh weight and $70 \%$ and $71 \%$ in root dry weight over control by NAA $1 \mathrm{mM}+\mathrm{CaCl}_{2} 1 \mathrm{mM}$ treatment during 2015 and 2016, respectively (Figure 3 ). The shoot length, fresh and dry weight displayed noticeable development with PGP treatments (NAA 1 $\left.\mathrm{mM}+\mathrm{CaCl}_{2} 1 \mathrm{mM}\right)$ as increase was $45 \%$ and $46 \%$ in shoot length, $35 \%$ and $36 \%$ in shoot fresh weight and $64 \%$ and $65 \%$ in shoot dry weight over control by treatment during 2015 and 2016, respectively (Figure 3 ). Chemically treated budchip showed significantly higher root and shoot parameters viz., length, fresh and dry weight. Their combined effect played a significant role in root and shoot initiation and growth (Figure 3). Sugarcane's budchip soaking in PGP helps in early and better establishment of seedlings (Figure 2) that resulted in higher root and shoot growth. Our findings are similar to Chengalrayan et al. (2005), they reported that application of PGP at initial stage significantly improved the shoot and root growth of sugarcane budchip. Moreover, calcium stimulates the root growth in other plants (Hepler, 2005). Indoleacetic acid is a synthetic auxin which play an important role in different growth progressions and stimulates root initiation and growth (Zhao, 2010).

\section{Conclusion}

From results of our experiment, it is concluded that pre-plant treatment of sugarcane budchips with plant growth promoters (NAA $1 \mathrm{mM})$ and $\mathrm{CaCl}_{2}(1 \mathrm{mM})$ solution improves their sprouting and seedling establishment. Hence, it improved the performance of novel budchip technology with a great scope for better seed handling at grower's level and improve sugarcane productivity.

\section{Acknowledgment}

The authors gratefully acknowledge the financial help rendered by the Office of Research, Innovation and Commercialization (ORIC), University of Sargodha, Sargodha, Pakistan.

Disclaimer: None.

Conflict of Interest: None.

Source of Funding: This study was financed by the Office of Research, Innovation and Commercialization (ORIC), University of Sargodha, Sargodha, Pakistan.

\section{References}

Aitken RL and McCallum LE, 1988. Boron toxicity in soil solution. Soil Res. 26: 605-610.

Chengalrayan K, Abouzid A and Gallo-Meagher M, 2005. In vitro regeneration of plants from sugarcane seed derived callus. In Vitro Cell Devel. Biol. Plant. 41: 477-482.

Dharmawardene MWN, 2006. Trends in farm mechanization by sugarcane small land holders in Sri Lanka. Sugar Tech. 8: 16-22.

El-Lattief EAA and Bekheet MA, 2012. Quantitative and qualitative attributes of three sugarcane varieties as influenced by foliar spray of some growth regulators under upper Egypt conditions. Sugar Tech. 14: 345-350.

FAO, 2019. OECD-FAO AGRICULTURAL OUTLOOK 2019-2028. Food and Agriculture Organization of the United Nations, Rome. $\mathrm{CH}$. 05. pp: 154-165.

Freed R, Eisensmith SP, Goetz S, Reicosky D, Smail VW and Wolberg P, 1991. Users Guide to MSTAT-C: a software program for the design, management, and analysis of agronomic research experiments. Michigan State University, East Lansing, MI, USA.

Govt. of Pakistan, 2018-2019. Economic Survey of Pakistan. Ministry of Finance, Government of Pakistan. pp. 11-34

Hayat Q, Hayat SM and Aqil A, 2010. Effect of exogenous salicylic acid under changing environment. Enviro. Exp. Bot. 68: 14-25. 
Hepler PK, 2005. Calcium: a central regulator of plant growth and development. The Plant Cell. 17: 2142-2155.

Iqbal MT, Eusufzal SUK and Rukshana F, 2002. Performance of sugarcane bud chip settlings. Indian J. Sugar. Technol. 17: 88.

Iqbal N, Nazar R, Khan MIR, Masood A and Kahan NA, 2011. Role of gibberellins in regulation of source-sink relations under optimal and limiting environmental conditions. Curr. Sci. 100: 9981007.

Jain R, Shrivastava AK, Solomon S and Yadav RL, 2007. Low temperature stress-induced biochemical changes in stubble bud sprouting in sugarcane (Saccharum sp. hybrid). Plant Growth Regul. 53: 17-23.

Jain R, Solomon S, Lal P and Shrivastava AK, 2009. Nutrient application improves stubble bud sprouting under low temperature conditions in sugarcane. Sugar Tech. 11: 83-85.

Jain R, Solomon S, Shrivastava AK and Chandra A, 2010. Sugarcane bud chips: A promising seed material. Sugar Tech. 12: 67-69.

Khan GS, 1986. Need for international crosschecking and correlation in soil analysis for international classification systems. In: Proceedings of the Twelfth International Forum on Soil Taxonomy and Agro-Technology Transfer: Soil Survey of Pakistan. Volume 1. Lahore: Director General, Soil Survey of Pakistan. pp: 276-293

Khan SA, Rashid H, Chaudhary MF, Chaudhry Z, Fatima Z, Siddiqui SU and Zia M, 2009. Effect of cytokinins on shoot multiplication in three elite sugarcane varieties. Pak. J. Bot. 41: 1651-1658.

Leite P, Narayan A and Skoufias E, 2011. How do ex ante simulations compare with ex post evaluations? evidence from the impact of conditional cash transfer programs. The World Bank.

Li YR and Solomon S, 2003. Ethephon, a versatile growth regulator for sugarcane industry. Sugar Technol. 5: 213-224.

Loganandhan N, Biksham G, Vinod GV and Natarajan US, 2013. Sustainable Sugarcane Initiative (SSI): A Methodology of 'More with Less'. Sugar Technol. 15: 98-102.

Mohanty M and Nayak PK, 2011. Economizing seed cane quantity by reducing sett size and bud number with sett treatment in sugarcane cultivation. Indian J. Sugar. Technol. 26: 59-60.
Mohanty SK and Sahoo NC, 2000. Effect of soaking period, seed size and growth regulators on imbibition and germination of seeds of some field crops. Orissa J. Agric. Res. Pub. CAB Abstracts.

Naqvi HA, 2005. Pakistan sugar book. Pakistan Society of Sugar Technologists. Mandi Baha-ud Din, Punjab, Pakistan pp: 1-250.

Patil RS, Patil DB, Patil DM, Shashikant B and Khandagale, 2018. Cam operated sugarcane bud cutting machine. Int. Res. J. Eng. Technol. 5: 140147.

Patnaik RJ, Singh SN, Debasis S and Nayak PK, 2016. Assessing potentiality of bud chip technology on sugarcane productivity, profitability and sustainability in real farming situations under South East Coastal Plain Zone of Odisha, India. Sugar Technol. 19: 373-377.

Paul IK and Savithri KE, 2003. Effect of bio-fertilizers vs. perfected chemical fertilization for sesame grown in summer rice fallow. J. Trop. Agric. 41: 47-49.

Paull JG, Cartwright B and Rathjen AJ, 1998. Responses of wheat and barley genotypes to toxic concentrations of soil boron. Euphytica. 39: 137144.

Reddy N, Keshavulu MK, Durga KK, Ankaiah R and Adrana K, 2009. Effect of nutrients alternate to GA3 on yield and quality in hybrid rice seed production. J. Res. Crops. 10: 718-722.

Ryan J, Estfan G and Rashid A, 2001. Soil and Plant Analysis Laboratory Manual. $2^{\text {nd }}$ edition. ICARDA, Aleppo, Syria. 172 p.

Solomon S, Shahi HN, Duttamajumder SK, Singh I and Madan VK, 2001. Effect of ethephon on sugarcane grown under subtropical climate. In: Proceedings of Int. Soc. Sugar Cane Technol. 24: 177-179.

Steel RGD, Torrie JH and DickyDA, 1997. Principles and Procedures of Statistics: A Biometric Approach. 3rd ed. New York: McGraw-Hill. pp. 178-198.

Systat Software Inc., 2008. SigmaPlot for Windows (development and testing procedures). Version 11.0. Triestram and Partner GmbH, Bochum, Germany.

White PJ and Broadley MR, 2003. Calcium in plants. Ann. Bot. 92: 1-25.

Wu L and Birch RG, 2007. Double sugar content in sugarcane plants modified to sucrose isomers. Plant Biotechnol. J. 5: 109-117. 
Zhang XJ, Li YR and Lin YK, 2001. Effects of different concentration of Ethephon soaking seed cane on agronomical characters and some physiological and biochemical characters in sugarcane stalk tissue. Sugarcane. 8: 14-19

Zhao Y, 2010. Auxin biosynthesis and its role in plant development. Annu. Rev. Plant Biol. 61: 49-64.

\section{Contribution of Authors}

Rehman A: Planned the experiment.

Hassan F: Performed experiment and collected data.

Qamar R: Prepared initial draft of manuscript. Rehman AU: Edited and gave final approval of manuscript. 